\title{
The role of headmaster to improve pedagogic competence of teachers in Vocational high school
}

\author{
Nellitawati Yusof Boon \\ Campus State University of Padang (UNP), Faculty of Education, Province of West Sumatra, Indonesia
}

\begin{abstract}
Teachers should not only be competent academically, but they should also possess pedagogical competence to be able to understand their students. However, each teacher needs guidance from the principals at each school. This study aims to determine the role of the principal in improving the pedagogical competence of teachers in vocational high schools. This study was conducted by conducting interviews and providing questionnaires to teachers in vocational high schools in PadangIndonesia. The results of this study indicate that a principal should be able to be educator, manager, administrator, supervisor, leader, innovator, and motivator for teachers at school. Although the role of principals is simple, it is very much needed by teachers. The principal's role significantly influences the teacher's pedagogical competence. In the future, a principal should be able to master every problem that exists in vocational high school.

Key words: the role of principals, pedagogical competence, competence of teachers, secondary vocational schools, professional principals.
\end{abstract}

\section{Introduction}

Government of Indonesia bill Number 20 of 2003 on National Education System stipulates that national education aims to develop the potential of students to become believers and to be devoted to the One True God, to be noble, healthy, knowledgeable, capable, creative, democratic and responsible citizens. In order to realize the government's expectations and to keep the community informed about it, it is imperative that qualified teachers be teachers with good competence so that they can carry out their duties and responsibilities in order to invigorate the nation of Indonesia [1].

One of the key aspects of the effort to improve the quality of education is to improve the quality of teachers by improving the competence of teachers maximally according to the conditions of teacher competency qualification towards professional teachers. This is because teachers play a very important role in the smooth running of the education process in the classroom, as well as determining the level of achievement of the learning process. Therefore, the construction of teacher quality and teacher competence should be done well [1], because teachers are the most important determinants in achieving educational excellence. Although there is a good curriculum and complete facilities, if no skilled teachers, educational excellence is difficult to achieve [2]. Teachers have an important role in designing the learning environment in the classroom [3].

The Sanusi study [4] shows that teachers' pedagogical competence is still categorized as low because teachers do not have the expertise in mastering the learning method. The low teachers' pedagogical competence could be seen from the process of teaching and learning, which is ineffective, inefficient and of low quality [5]. The role of school principals can be seen in Figure 1 below.

In addition to the competence of teachers, quality of education is strongly influenced by the leadership role of the school principal $[6,7,8]$. Therefore, to achieve quality education, a school principal must be competent to carry out its role in school. Therefore, all activities in the school are the responsibility of the principal. In addition, principals have the primary task of giving guidance and motivation to teachers and staff in implementing teaching and learning in schools, as well as giving teachers the freedom to use school facilities [9].

Role of principals is often expressed as educators for teachers and school staff in order to create a harmonious atmosphere and to improve teachers' competency $[10,11]$. Managing one of the most important things in an organization, in this case the school, the school organization manages the process of organization, organization, direc- 


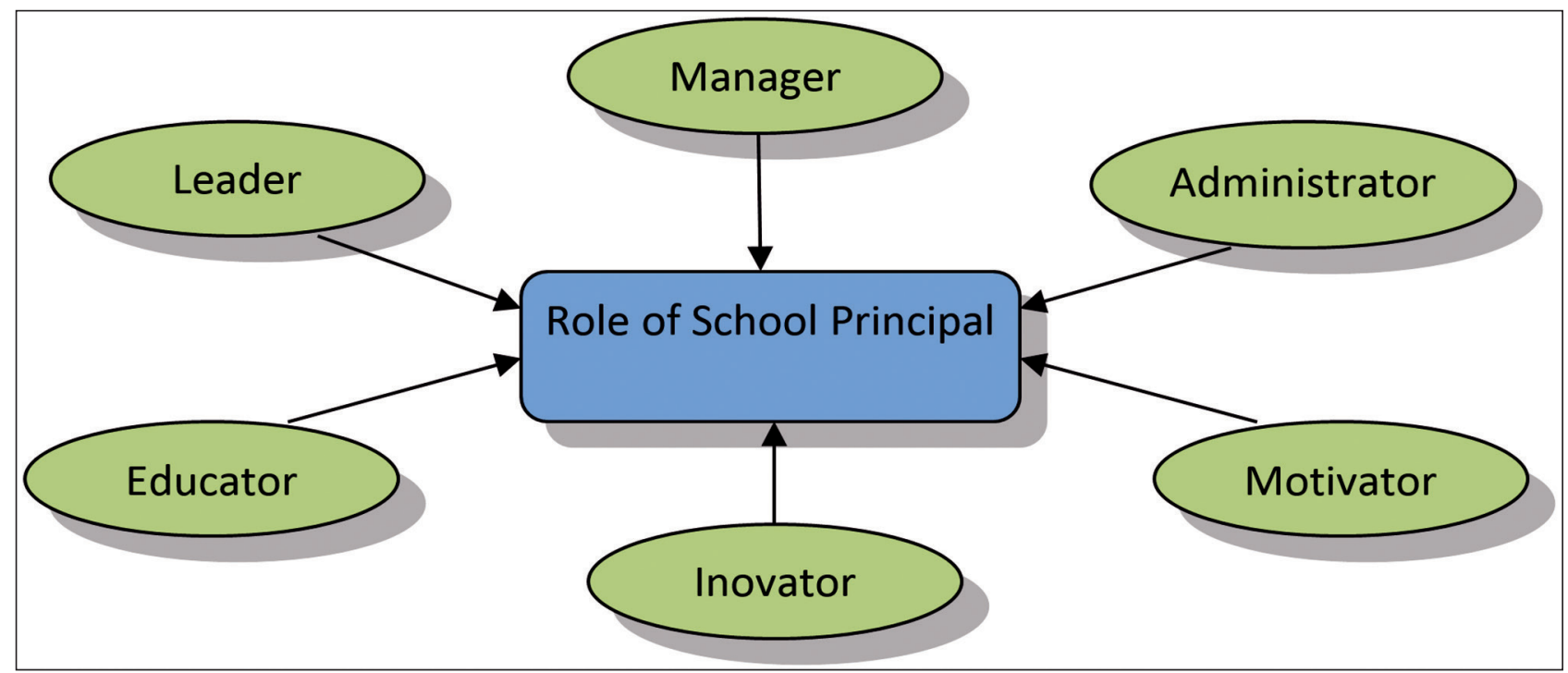

Figure 1. Role Model School Principal

tion and control of all members of the organization and strengthens the organization's resources to achieve the organization's intended purpose. In addition, school leaders must have expertise in school management to coordinate the implementation of educational administration programs, administrative procedures and records, staff administration, financial administration and administrative and administrative facilities of students. These activities need to be done in an efficient and effective way to support school productivity [12].

School principals must work with teachers as supervisors in developing programs to be implemented. As school supervisors, principals are responsible for carrying out supervisory activities on the implementation of the learning process and the way in which teachers implement the curriculum to develop the quality of education in schools $[13,14]$. In addition, principals must monitor the activities carried out by school leaders to protect the implementation of principles designed together through collaborative relationships [15].

Behbahani [16] states that principals in leadership must apply leadership styles to suit the circumstances and needs. This is particularly important in promoting creativity in enhancing teacher competence. The role of school principals as the leader is the ability to achieve the goals based on the vision of school missions by leveraging the public in the school environment.

Hallinger et al. [17] explain that the ability to achieve success in school includes the role of school principals to provide new ideas and support teachers to have high knowledge, skills and motivation. Crow and Peterson [18] revealed that the school principal as an innovator has the ability to develop goals to promote and mobilize the entire staff in the organization he leads to perform the best work. School principals should have new creativity and thought to facilitate translating school vision and mission, and school principals must have the ability to carry out investigations in their role [19].

As motivator, school principals should have the right strategic principles and be able to provide advice to ensure maximum work output of subordinates [20]. This motivation can be done well when the work environment / school is good, a pleasant work environment and discipline culture is well maintained, using reward as motivation for educational personnel [14].

The pedagogical competence is the ability of teachers to understand the characteristics of students in terms of emotional, moral, and intellectual aspects. It requires a teacher to have the ability to master the learning theory and the principles of learning, because students have different characters, traits, and interests. This ability enables teachers to understand the willingness and readiness of their students in a process of teaching and learning.

\section{Methodology}

Implementation of research is conducted by an unequal combination method or Concurrent 
Embedded Mixed Method Design [21,22]. This study was conducted at 10 State Vocational High Schools in Padang City. The teacher population in Padang City, according to Padang City Diknas, is 865 people spread over 10 vocational high schools in Padang City.

The use of interview as a data gathering instrument was conducted on selected teachers and school principals through sampling methods aimed at interview. The main purpose of the interview is to obtain information about the role of school principals in improving teacher competence.

In this study, two types of questionnaires were used, namely the questionnaire on the role of school principals and questionnaires on teacher competence. The questionnaire consisted of questionnaires about the role of school principals in improving teacher competence, and questionnaire about teacher's own competence. The questionnaire consists of three parts, and included the background of the respondent, the role of the school principal, and the teacher's competence.

This study uses an unstructured interview. The selection of this type of interview is intended to enable the researcher to ask questions unambiguously and to ask opinions or ideas about the issues being interviewed, making it possible to obtain more open information. In order to do so, an interviewer should provide tools such as compact discs or records so that all information presented by the information can be recorded.

Quantitative analysis is the process of displaying data and interpreting quantitative data [23]. Quantitative analysis is also used to make the generalization of the sample into the population, meaning the phenomenon or occurrence of the study sample obtained from the analysis results can be generalized to the population. Furthermore, Tiro [24] argues that in order to obtain the answers to the questionnaire, the data analysis method must be in line with the study pattern and the variables studied. In this study, there are two types of data, namely quantitative data obtained through the questionnaire and the types of qualitative data obtained from interviews with respondents. The survey data analysis methods used a combination of methods (mixed methods).

In line with the research, there are two types of data analysis, namely quantitative and qualita- tive data analysis. Especially for quantitative data analysis, survey group B and C, researchers are using the application program SosialScience Statistical Package for Social Sciences (SPSS) for Windows 21.0. In this case, the analysis of the research data was done by using descriptive analysis and increment analysis at the significance level of $0.05(\mathrm{a}<0.05)$. Explanation of the use of both types of statistical analysis is shown in the following descriptions.

\section{Results and discussion}

\section{a) The principal role of the teacher}

Based on Table 4.6, it is shown that the role of principals as educators is moderate because their mean value is 3.65 with standard deviation .783 , which means that the role of the principal as educator needs to be increased to increase the competency of state vocational high school teachers in Padang City. The numbers expressed as frequencies and percentages also indicates the role of principals as educators is always moderate but medium-level categories are high because the dimensions are almost gradually high, where the number of 4 points is more than half, recording 138 and 52.9 percent. It is also found that the role of a principal as a manager is simple because the mean value is only 3.45 with the standard deviation of .749. Most of the frequencies are in the 4 point scale of 115 , or 44.1 percent. It is of the utmost importance that principals' ability to improve their role in improving teacher competence continues to be enhanced.

Table 1 shows that the role of principals as an administrator should be enhanced as descriptively it is found that the role of principals is still moderate in relation to improving teacher competence. This is due to the mean value of the moderate graduated teachers of 3.41 with the standard deviation of 0.758 . The number of frequencies is mostly in the 3 point scale of 112 or 42.9 percent and 4 point scale, which is 104 or 39.9 percent. Because the majority are on the 3-point scale, the stage is simple. The same thing happens to the role of the principal as a moderate supervisor because the mean value is only 3.51 with the standard deviation of 0.719 . The number of frequencies shows the same as the majority of the respondents' perceptions on the role of the principal on a 4-point scale of 114 or 43.7 per 
Table 1. Descriptive Analysis Based on the findings of Phase Role of Principals

\begin{tabular}{|c|c|c|c|c|c|c|c|c|c|}
\hline \multirow[b]{2}{*}{ Variable } & \multicolumn{5}{|c|}{ SKALA } & \multirow{2}{*}{$\begin{array}{l}\text { Number } \\
\text { of items }\end{array}$} & \multirow[b]{2}{*}{ Min } & \multirow{2}{*}{$\begin{array}{l}\text { Standard } \\
\text { deviation }\end{array}$} & \multirow[b]{2}{*}{ Stage } \\
\hline & \begin{tabular}{|c|} 
STS \\
No $(\%)$ \\
\end{tabular} & \begin{tabular}{c|} 
TS \\
No $(\%)$ \\
\end{tabular} & \begin{tabular}{|c|} 
TP \\
No $(\%)$ \\
\end{tabular} & \begin{tabular}{|c|} 
S \\
No $(\%)$ \\
\end{tabular} & \begin{tabular}{|c|} 
SS \\
No $(\%)$ \\
\end{tabular} & & & & \\
\hline For Educators & $\begin{array}{c}3 \\
(0.2)\end{array}$ & $\begin{array}{c}19 \\
(7.3)\end{array}$ & $\begin{array}{c}63 \\
(24.1) \\
\end{array}$ & $\begin{array}{c}138 \\
(52.9)\end{array}$ & $\begin{array}{c}38 \\
(14.6) \\
\end{array}$ & 6 & 3.65 & 0.783 & Simple \\
\hline As Manager & $\begin{array}{c}5 \\
(1.9)\end{array}$ & $\begin{array}{c}25 \\
(9.6)\end{array}$ & $\begin{array}{c}95 \\
(36.4)\end{array}$ & $\begin{array}{c}115 \\
(44.1)\end{array}$ & $\begin{array}{c}11 \\
(4.2)\end{array}$ & 5 & 3.45 & .7490 & Simple \\
\hline As Administrator & $\begin{array}{c}5 \\
(1.9)\end{array}$ & $\begin{array}{c}24 \\
(9.2)\end{array}$ & $\begin{array}{c}112 \\
(42.9)\end{array}$ & $\begin{array}{c}104 \\
(39.9)\end{array}$ & $\begin{array}{c}16 \\
(6.1)\end{array}$ & 5 & 3.41 & 0.758 & Simple \\
\hline As Supervisor & $\begin{array}{c}3 \\
(1.1) \\
\end{array}$ & $\begin{array}{c}20 \\
(7.7) \\
\end{array}$ & $\begin{array}{c}100 \\
(38.3) \\
\end{array}$ & $\begin{array}{c}114 \\
(43.7) \\
\end{array}$ & $\begin{array}{c}24 \\
(9.2) \\
\end{array}$ & 5 & 3.51 & 0.719 & Simple \\
\hline As leader & $\begin{array}{c}5 \\
(1.9) \\
\end{array}$ & $\begin{array}{c}19 \\
(7.3) \\
\end{array}$ & $\begin{array}{c}114 \\
(43.7) \\
\end{array}$ & $\begin{array}{c}102 \\
(39.1) \\
\end{array}$ & $\begin{array}{c}15 \\
(5.7)\end{array}$ & 6 & 3.37 & 0.775 & Simple \\
\hline As an Innovator & $\begin{array}{c}2 \\
(0.8)\end{array}$ & $\begin{array}{c}15 \\
(5.7)\end{array}$ & $\begin{array}{c}86 \\
(33.0)\end{array}$ & $\begin{array}{c}125 \\
(47.9)\end{array}$ & 33 (12.6) & 4 & 3.55 & 0.742 & Simple \\
\hline As motivator & $\begin{array}{c}1 \\
(0.4)\end{array}$ & $\begin{array}{c}20 \\
(7.7)\end{array}$ & $\begin{array}{c}91 \\
(34.9)\end{array}$ & $\begin{array}{c}134 \\
(51.3)\end{array}$ & $\begin{array}{c}15 \\
(5.7)\end{array}$ & 5 & 3.53 & 0.650 & Simple \\
\hline \multicolumn{6}{|c|}{ Min Overall Role of Principal } & 36 & 3.50 & 0.659 & Simple \\
\hline
\end{tabular}

Table 2. Descriptive Analysis Based on the findings of Teacher Competency Level

\begin{tabular}{|c|c|c|c|c|c|c|c|c|c|}
\hline \multirow[b]{2}{*}{ Variable } & \multicolumn{5}{|c|}{ SKALA } & \multirow{2}{*}{$\begin{array}{c}\text { Number } \\
\text { of items }\end{array}$} & \multirow[b]{2}{*}{ Min } & \multirow{2}{*}{$\begin{array}{l}\text { Standard } \\
\text { deviation }\end{array}$} & \multirow[b]{2}{*}{ Stage } \\
\hline & $\begin{array}{c}\text { STS } \\
\text { No }(\%) \\
\end{array}$ & $\begin{array}{c}\text { TS } \\
\text { No }(\%)\end{array}$ & $\begin{array}{c}\text { TP } \\
\text { No (\%) } \\
\end{array}$ & $\begin{array}{c}\text { S } \\
\text { No }(\%) \\
\end{array}$ & $\begin{array}{c}\text { SS } \\
\text { No }(\%) \\
\end{array}$ & & & & \\
\hline $\begin{array}{l}\text { Pedagogical } \\
\text { aspects }\end{array}$ & $\begin{array}{c}2 \\
(0.8)\end{array}$ & $\begin{array}{c}18 \\
(6.9)\end{array}$ & $\begin{array}{c}90 \\
(34.5)\end{array}$ & $\begin{array}{c}139 \\
(53.3)\end{array}$ & $\begin{array}{c}12 \\
(4.6)\end{array}$ & 9 & 3.50 & 0.646 & Simple \\
\hline $\begin{array}{l}\text { Personality } \\
\text { Aspects }\end{array}$ & - & $\begin{array}{c}24 \\
(9.2)\end{array}$ & $\begin{array}{c}92 \\
(35.3)\end{array}$ & $\begin{array}{c}124 \\
(47.5)\end{array}$ & $\begin{array}{c}24 \\
(9.2)\end{array}$ & 6 & 3.49 & 0.755 & Simple \\
\hline $\begin{array}{l}\text { Professional } \\
\text { aspect }\end{array}$ & - & $\begin{array}{c}6 \\
(2.3)\end{array}$ & $\begin{array}{c}98 \\
(37.6)\end{array}$ & $\begin{array}{c}140 \\
(53.6) \\
\end{array}$ & $\begin{array}{c}17 \\
(6.5) \\
\end{array}$ & 7 & 3.64 & 0.579 & Simple \\
\hline Social aspects & - & $\begin{array}{c}13 \\
(5.1)\end{array}$ & $\begin{array}{c}61 \\
(23.4)\end{array}$ & $\begin{array}{c}110 \\
(42.2)\end{array}$ & $\begin{array}{c}77 \\
(29.5)\end{array}$ & 6 & 3.83 & 0.759 & Height \\
\hline \multicolumn{6}{|c|}{ Overall Mean Teacher Competence } & 28 & 3.62 & 0.485 & Simple \\
\hline
\end{tabular}

cent and a 3-point scale of 100 or 38.3 per cent. The role of principals as a leader is also simple, because the mean value is 3.37 with the standard deviation of 0.775 . The number of frequencies and percentages can be supported as the majority are on a 3-point scale with a frequency of 114 or 43.7 per cent and a 4-point scale of 102 or 39.1 per cent. It means that the role of principals as leaders has not been felt by teachers in improving their compatibility.

It is also found that the role of the principal as an innovator and motivator is also at moderate level as the mean value of the role of the principal as an innovator is 3.55 with the standard deviation of 0.742 and as the motivator has a mean value of 3.53 with the standard deviation of 0.650 . This finding also means that the role of principals in improving teacher competence on the side of innovation and motivation is still needed to be improved. Both principals' roles have the majority of perceptions on the 4-point scale but many teachers also give perceptions at the 3-point scale.

\section{b) Vocational High School teacher competency}

Based on Table 4.7 it is found that overall the level of teacher competence is moderate because the mean value is 3.62 with the standard deviation of 0.485 . This finding means that teachers' overall competence in Padang City is still moderate and should be noted by principals and stakeholders such as government leaders. 
While being observed alone, it is found that there is only one dimension of teacher competence that has a high degree of social competence as the mean value is 3.83 with a standard deviation of 0.759. According to the number of frequencies, one teacher's competence was found at a 4-point scale of 110 (42.2 percent) and a 5-point scale of 77 (29.5 percent). This finding also implies that the competence of state vocational high school teachers in Padang City has a social life because of the high level of feedback by teachers.

It is also found that teachers' competence as pedagogy is moderate because their mean value is 3.50 with standard deviation 0.646 . It was found that the majority of the frequency was on a 4-point scale of 139 or 53.3 per cent. This means that the teachers have a high degree of competence on the pedagogical side. This is interesting because they should have pedagogical skills in carrying out their duties as educators for their students, but this is not the reality. Therefore the teacher's competence on this side is very important.

\section{c) Role of Principals on Teacher Competence}

The findings of multiple linear regression analysis as in Table 3 show that overall the role of principals on teachers' competence is significant because the significant value of $F(12.984)$ is 0.000 . The significant decision of the principal role of teacher competence was significant and the fifth hypothesis of the study was unacceptable or rejected because sig value was 0.000 less than the value of alpha 0.05 .
In Table 3, this study also found that the influence of principals' role dimensions was 28.7 percent. It means that overall principals' influence is only 28.7 percent or there are other factors that influence teacher competence but are not included in this study. This is supported by a high or constant value of 3.338 and a significant value of 0.000 . It can be seen that there are three dimensions or indicators of role of principals that do not significantly affect teachers' competence i.e. the role of principals as managers because their significant value is greater than alpha $(0.933>0.05)$. This finding implies that the role of the principal as a manager needs to be improved to ensure the competence of teachers in carrying out their duties.

Second is the role of the principal as an administrator with a significant value greater than the alpha value of 0.775 , which is greater than 0.05 . This finding gives the sense that the principals as administrators really need to pay attention to the competence of teachers so that could affect the success of the assignment of the state vocational secondary school teachers in the city of Padang. Finally, it is found that an indicator that does not significantly affect the competence of the teacher is the role of the principal as a leader because the significant value is higher than the alpha value $(0.491>0.05)$. It is therefore imperative for all principals to be able to play their role as a leader in the success of teacher competence.

Further findings shown in Table 3 are indicators or dimensions of the role of the state vocational

Table 3. The results of regression analysis constructs of the influence of the role of Principal in Teachers Competency

\begin{tabular}{|l|r|r|r|}
\hline \multicolumn{1}{|c|}{ Role of Principal / Independent Variables } & \multicolumn{1}{c|}{$\hat{\mathbf{I}}^{\mathbf{2}}$} & \multicolumn{1}{c|}{$\boldsymbol{T}$} & \multicolumn{1}{c|}{ Sig } \\
\hline Constant / Constant & 3.338 & 20.871 & 0000 \\
\hline As an Educator & 0.148 & 2.406 & 0.017 \\
\hline As a Manager & -.009 & -0.085 & 0.933 \\
\hline As Administrator & 0.033 & 0.287 & 0.775 \\
\hline As Supervisor & 0.244 & 4.056 & 0.000 \\
\hline As a Leader & -0.225 & -0.716 & 0.491 \\
\hline As an Innovator & 0.297 & 3.103 & 0.002 \\
\hline As Motivator & 0.219 & 2.330 & 0.021 \\
\hline $\begin{array}{l}\text { The dependent variable: Teacher Competence } \\
\text { adj } \mathrm{R}^{2}=.287\end{array}$ & & & \\
$\mathrm{R}=.514 \mathrm{~F}=12.984$ & & & \\
$\mathrm{R}^{2}=.309$ sig $=.000$ & & & \\
\hline
\end{tabular}


high school principals in the city of Padang, which significantly affect the competence of teachers. Comparative indicators are the role of principals as educators, the role of principals as supervisors, the role of principals as innovators and the role of principals as motivators.

\section{d) Teacher competence based on interview results}

This qualitative section is used to support the quantitative analysis of answers in the first study question. To illustrate the findings of the qualitative study according to the level of competence of the teacher, the first researcher shows that as many percent of respondents give an impression frequency on this question.

Based on Table 4, the frequency of respondents who responded to the socio-competence level of the teachers had the highest number of respondents interviewed i.e. five or 83 percent of respondents, with only one or 17 percent of respondents who stated moderate. Interviewees were interviewed about the involvement of teachers in social activities that could contribute to increasing the competence of teachers as educators. While the frequency and percentage of respondents' perceptions were the lowest in the pedagogical competence of teachers, it was found that only four or 67 percent of respondents gave a moderate statement and there were two or 33 percent who stated that they were low. This finding also meant that although the frequency and percentage were low, the respondents had to give almost all the statements across the respondents.

Furthermore, teachers' professional competence faced five or 83 percent of the respondents who stated moderate and one or 17 per cent of respondents who said they were low. Finally it was found that teachers' personality competence aspect had a high level of three or 50 percent of respondents and three or 50 percent saying moderate.

The low level of teacher competence is very unlikely to motivate its students to achieve high quality as the ratio pedagogical competence is directly attributable to the knowledge of students [25]. Since teachers are competent in pedagogy, there is no other way that the government can provide assistance to teachers to improve their pedagogical competence. One thing the government can do is to help teachers to improve pedagogical skills by continuing their education to higher levels or assisting them to include teachers at each workshop appropriate to the field of expertise [26].

The teacher's competence in the learning process is very important as this factor is the spearhead of the school to make the student outdoors. Therefore, teachers must have competence in accordance with applicable standards [27]. To identify the problems faced by teachers in improving their competence, interviews are described in this section. Based on interview findings, the following will be explained by the respondents involved in the interview starting from the same opinion about the absence of a problem in the aspect of teacher pedagogy competence.

\section{Conclusion}

The principals' role significantly affects the ability to succeed in pedagogy of vocational high school vocational school teachers in Padang City. Overall it can be concluded that the principal has a major role in improving the pedagogical competence of teachers and it is necessary that all indicators roles can give a significant effect on the competence of the state vocational high school teacher in the city of Padang.

Table 4. Frequency and Percentage of Respondents Who Respond Based on Teacher Competency Level

\begin{tabular}{|c|l|c|c|c|c|c|c|}
\hline \multirow{2}{*}{ Number } & \multirow{2}{*}{ Teacher competency } & \multicolumn{6}{|c|}{ Stage } \\
\cline { 3 - 8 } & & \multicolumn{2}{|c|}{ Height } & \multicolumn{2}{|c|}{ Simple } & \multicolumn{2}{c|}{ Low } \\
\cline { 3 - 8 } & & No & $\mathbf{( \% )}$ & No & $\mathbf{( \% )}$ & No & $\mathbf{( \% )}$ \\
\hline 1 & Pedagogy competence & - & 0 & 4 & 67 & 2 & 33 \\
\hline 2 & Personality competence & 3 & 50 & 3 & 50 & - & 0 \\
\hline 3 & Social competence & 5 & 83 & 1 & 17 & - & 0 \\
\hline 4 & Professional competence & - & 0 & 5 & 83 & 1 & 17 \\
\hline
\end{tabular}




\section{Reference}

1. Zulfikar T. The Making of Indonesia Education: An Overview on Empowering Indonesia Teachers. Indonesia SocialSciences and Humanities, 2009; Vol. 2.

2. Wannasir. Contributions Supervsi motivation and the performance of teachers. The thesis is not postponed Padang Post Graduate Program Padang State University, 2002.

3. Blankmeyer M, Flannery DJ, Vazsonyi AT. The role of aggression and social competencein childrend's perceptions of the child-teachar relationship. Psychology in the school, 2002; 39(3): 293-304.

4. Sanusi A. Facts, Policy, Science, Education philosophy. Lecture Materials. Bandung: PPS UNINUS, 2007.

5. Sarkadi Y, Raharja Y. Factors Contributing to Low Pedagogic Competence Teachers in Jakarta: A Descriptive Study in elementary school, junior high, high school / vocational school in East Jakarta District Pulogadung. 2006; 10.

6. Arni M. Profile Teachers Implementing the task at City National High School Bukittingi Unpublished Research Report Department of Education Administration Course FIP UNP, 2008.

7. Muhson A. Improving Teacher Professionalism: A Hope, Journal of Economics and Education, 2004; 2(1).

8. Firdawati Y. Contributions school principal leadership and professionalism of teachers on teacher performance in the Junior High School in the District of silk; The thesis is not published. Padang. Padang State University Graduate Program, 2013.

9. Yuyarti. Role of School Principals in Learning Quality Improvement Management. $R \&$ D Journal of Prov. Central Java, 2009; 7(2): 133-140.

10. Mulyasa. Implementation of Curriculum Education (Fatna Yustianti ed.). Jakarta: Bumi Aksara, 2009.

11. Mukhtar A. New Oriantasi Education Supervision. Jakarta: Gaung Persada Press, 2009.

12. Drake TL, Roe WH. The principalship. Edisi 3. New York: Macmillan Publishing company, 1986.

13. Hussein M. Leadership and School Effectiveness. Kuala Lumpur: The Language and Literature Council, 1993.

14. Spenbauer S. A Quality System for Education Sydney: New York: McGraw-Hill Book Company, 1992.

15. Gulsen C, Ates A, Bahadir E. The thoughts of school principals about the effects of educational supervisors on training of teachers in terms of professions, 2014.
16. Behbahani, Aliakbar. Educational Leaders and Role of Education on the Efficiency of Schoolsâ $€$ тм Principals. WCES-2011. Procedia Elsevier. 2011; 15 : 9 .

17. Hallinger Ph. Lee M. Exploring Principal Capacity to Lead Reform of Teaching and Learning Quality in Thailand. International Journal of Educational Development, 2013; 33: 305-315.

18. Crow GM, Peterson KD. Principals Role in Restructuring School. Leadership and Management $\hat{a}$ $€$ "Politics and Governance, 2010.

19. Soleimani N, Persian E. A Study of the Relationship between Principals' Creativity and Degree of Environmental Happiness in Semnan High Schools. International Conference on Education and Educational Psychology (ICEEPSY 2011). Procedia 29; 2011; 1869-1876.

20. Nyaribo M, Prakash A, Edward O. Motivators of Choosing a Management Course: A Comparative Study of Kenya and India. The International Journal of Management Education. Elsevier. 2012; 10: 201-214.

21. Sugiyono. Educational Research Methods: Quantitative Approach, Qualitative and $R \& D$. Bandung: Alfabeta, 2011.

22. Creswell JW. Research Design_Qualitative, Quantitative, and Mixed Method Approaches. Sage Publications, Inc.California, 2014.

23. Noraini I. Research in Education. Kuala Lumpur: McGrawHill (Malaysia) Sdn. Bhd. 2010.

24. Tiro MA. Statistical Basics (Revised EIS). Makasar: State University of Makasar Press, 2001.

25. Hennessy $S$, Deaney R, Ruthven K. Emerging teacher strategies for supporting subject teaching and learning with ICT. Curriculum Journal, Faculty of Education, Cambridge University, UK, 2005.

26. Barnes T. Kaizen Strategies for Successful Leadership. Jakarta: Interaksara. 1998.

27. Huber SG. New Approaches in Preparing School Leaders. Leadership and Management â $€$ "Leader Preparation. Elsevier, 2010.

Corresponding Author

Yusof Boon Nellitawati

Campus University Negeri Padang (UNP),

Faculty of Pendidikan Provinsi,

Sumatera Barat,

Indonesia,

E-mail:nellitawati61@gmail.com 